\title{
Neurosurgery at the Toronto General Hospital, 1924 - 1990: Part 1
}

\author{
J. Max Findlay
}

\begin{abstract}
“. . . not only do the old forget but the younger men do not always know much more than the names of those predecessors who went before them, leaving the doors open for others to walk through. Especially do they not know what struggles these predecessors had with the inertia of their own days, the heartaches, the frustrations that they experienced. How sparse was the straw available for their brick-making!"
\end{abstract}

Sir Geoffrey Jefferson, on the occasion of the opening of the Neurosurgical Unit of the Toronto General Hospital, November 8, 1958.

Can. J. Neurol. Sci. 1994; $21: 146-158$

The specialty of neurological surgery in this country began when Kenneth G. McKenzie was appointed to the Toronto General Hospital surgical staff in 1924, Canada's first dedicated neurosurgeon. In the years and decades that followed McKenzie and his successors established the Toronto General Hospital as one of the leading clinical and teaching neurosurgical units in the world. It was not without some sadness, therefore, that in 1990 neurosurgery left the walls of the Toronto General Hospital, the service transferred to join with the neurosurgical division of a sister hospital, the Toronto Western, during a merger which created the new, two-site, Toronto Hospital. The following story is of the men and women at the Toronto General Hospital who provided, advanced, and taught neurosurgical care. Many persons, among them orderlies, nurses and physicians, will not receive the mention they deserve in the pages that follow, but are no less remembered.

\section{Kenneth George McKenzie and the Beginning of Neurosurgery in Canada}

The life and career of this much-admired pioneer of Canadian neurosurgery has been chronicled by E. Harry Botterell, ${ }^{1}$ and Eben Alexander, Jr. commemorated Dr. McKenzie in his presidential address to the Society of Neurological Surgeons in $1973 .{ }^{2}$ Perhaps the single greatest contribution made to Canadian neurosurgery was McKenzie's first, and that was, as Botterell put it, "his courage to commit himself to the field of neurosurgery when he did, and to persevere and develop the first neurosurgical service in Canada". ${ }^{1}$

\section{Surgical training}

Kenneth G. McKenzie, of Scottish descent, was born in Toronto in 1892. Dr. McKenzie attended the University of Toronto, graduating from medical school as silver medallist in 1914 at age 22. He served in the British and then Canadian Royal Army Medical Corps in World War I, first in France and then in the Middle East, from 1914 to 1917. Following the war McKenzie began general practice in Toronto, working as well at the Christie Street Veteran's Hospital, and demonstrating anatomy for medical students at the University of Toronto. Pursuing his long-held dream to become a surgeon, McKenzie took a correspondence course from England since there were no post-graduate training programs for surgery in Canada at that time. However, four years would pass before an opportunity arose.

In 1922 Harvey Cushing, at the height of his career in neurosurgery, was awarded the second Charles Mickle Fellowship from the University of Toronto, and he generously offered the $\$ 1000$ honorarium towards the training of a Canadian in neurosurgery. McKenzie petitioned Toronto's Professor of Surgery C.L. Starr for the position, and was accepted. In his own description of these events, McKenzie felt that competition was not keen since results and mortality rates in neurosurgery at the time were still most discouraging, and it was considered a "decidedly unpromising field for a surgical career". 3

As was the rule on Cushing's service, McKenzie, a mature 31-year-old war veteran and father of three, went for his training in Boston alone, without the distraction of an accompanying family. He spent an arduous year over 1922-1923 as Assistant Resident in Surgery in charge of the Neurosurgical service at the Peter Bent Brigham Hospital. McKenzie later described this formative time and provided a penetrating glimpse into both the genius and daily life of his neurosurgical mentor, Harvey Cushing. ${ }^{4}$

On returning to Toronto in 1923 McKenzie became the second C.L. Starr resident in General Surgery at the Toronto General Hospital, and after completion of his surgical training was appointed to the surgical staff of this hospital in 1924, subspecializing in neurosurgery.

\footnotetext{
From the Division of Neurosurgery, University of Alberta, Edmonton. RECEIVED APRIL 15, 1993. ACCEPTED IN FINAL FORM OCTOBER 29, 1993.

Reprint requests to: J. Max Findlay, M.D., University of Alberta, Department of Surgery, 2D1.02 Mackenzie Health Sciences Centre, 8440 - 112 Street, Edmonton,
} Alberta, Canada T6G 2B7 


\section{The McKenzie Service, and the Origins of Neuropathology and Neurology at Toronto General Hospital}

The prevailing mortality and morbidity rates associated with brain surgery at the time of McKenzie's appointment made this a most inauspicious beginning. The practice of neurosurgery then can be scarcely imagined today. McKenzie later wrote: 5

"I look back to the time when an operation was scheduled in any one of the general surgical operating rooms that happened to be free in the afternoon. The nurses and house-surgeons were tired because they had already completed a full day's work. For the most part it was their first experience. These were the days before suction, endotherm, and the tracheal tube to assist the anaesthetist. Control of bleeding from the brain depended on the application of fresh muscle obtained, not always with good grace, from a surgeon who had done an abdominal operation in the morning. Because of the difficulties with anaesthesia and the control of hemorrhage, the operations were long and exhausting to all concerned."

Yet with fortitude and perseverance McKenzie endured the difficult, early years, when he faced a mortality rate for brain tumors that would have defeated a lesser surgeon.

Frank Turnbull recalls (personal communication, 1992):

"During his depressed moods, usually despairing about the limitations of neurosurgery, a triumvirate of females sustained and boosted his morale: the faithful Miss Duthie (his secretary for many years and to whom almost every resident would turn to learn the ropes), his wife Irene ("Poor Ken. He's had another of those bad operations"), and an elderly Scot nursing supervisor, who had been "on nights" for years at T.G.H., and who had consoled him ever since his early years when so many operations for brain tumors ended fatally. Sometimes when he was despondent, he would unexpectedly go fishing for the weekend, or out to the country to visit his father, a family doctor, leaving me with sole responsibility for some acutely ill patients."

Gradually techniques improved, and both McKenzie's reputation, and his practice, grew. He compensated for the lack of intern or resident assistance by the development of a scrub nurse familiar with neurosurgical technique who could also assist. In 1930 the first operating room nurse dedicated to neurosurgery was appointed, the talented Janet MacMillan. In 1930 McKenzie began Canada's first full-year neurosurgical training program, and in 1931 he helped convince the University to appoint a full-time neuropathologist.

Dr. Eric A. Linell had come from Manchester in 1921 to become an assistant professor in anatomy at the University of Toronto, teaching neuroanatomy to medical students, and he began receiving neurosurgical material for study in the anatomy department as Dr. McKenzie established neurosurgery at the Toronto General Hospital. Stimulated by his association with McKenzie, he agreed to establish a new division of neuropathology within the Department of Pathology at the Banting Institute in 1932. Dr. Mary I. Tom, who graduated in medicine from the University of Toronto in 1922, was developing histological techniques for Professor McMurrich when she was transferred to the newly opened Banting Institute under Dr. Linell. These were the first two faculty positions in neuropathology in Canada (Figure 1). Prof. Linell concentrated on brain cutting and gross pathology, as well as teaching medical students, while Mary

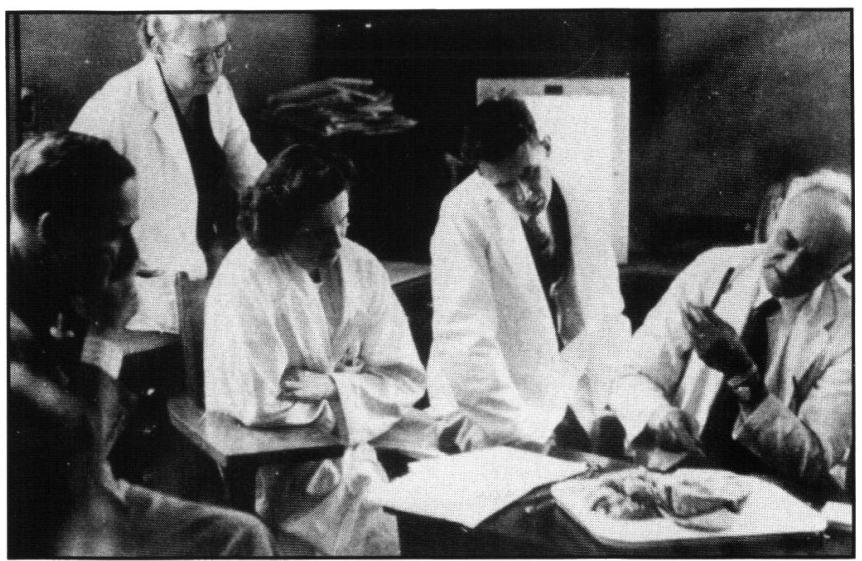

Figure 1: Brain cutting at the Banting Institute with Professor Eric Linell (at right), and Dr. Mary Tom (upper left), circa early 1950's. Photograph courtesy of Dr. Barry Rewcastle.

Tom was the microscopist. McKenzie had a particularly close and warm relationship with the neuropathologists, often rushing over to the Banting to discuss an interesting case and take refuge in the relaxed, pipe-smoke-filled atmosphere of Prof. Linell's laboratory.

Dr. McKenzie's work was also partly responsible for a renewed interest in neurology in Toronto General's Department of Medicine. Dr. Herbert H. Hyland, after studying medicine in England including 8 months of neurology at Queen Square, was appointed as medical consultant and neurologist in $1930 .{ }^{6}$ Hyland collaborated effectively with his colleagues in neurosurgery and neuropathology, and helped establish the tradition of clinical liaison between the neuroscience specialties at the Toronto General Hospital.

Urology was the first surgical specialty to be established at the University of Toronto, and neurosurgery second. In 1936 a dedicated neurosurgical operating room was introduced ("D.O.R."), as was a unit office and secretary, Anne Pyke. The "McKenzie Service" was now well established.

\section{McKenzie the Surgeon}

By all accounts, McKenzie became a brilliant technical surgeon. One of his colleagues described him as "... the most dexterous of brain surgeons. He was a magician, with economy of movement, sure of the next step, unfaltering and unflappable."7 Dr. Charles Drake has said that McKenzie was "... a beautiful surgeon, imperturbable: there were none better, and perhaps none as good ... in the world at that time." (personal communication, 1992). McKenzie constantly tried, with considerable success, to improve both the technique and instrumentation of neurosurgery. Several of his first responsibilities at the Toronto General Hospital were treating trigeminal neuralgia and brain abscess, and his difficulties and surgical solutions to those problems were subjects of lucid and well-illustrated technical reports soon after he commenced practice. ${ }^{8.9}$ In time, McKenzie became particularly adept at the surgical treatment of tic douloureux. One McKenzie resident, Dr. Bill Stevenson, recalls: "Dr. McKenzie would do the Frazier operation for tic, in 15-20 minutes start to finish. Speed is not so important nowadays, but K.G. never wasted any time." (personal communication, 1992). 


\section{McKenzie 's Contributions to Neurosurgery}

As early as 1927 McKenzie won the gratitude of his colleagues by making some "minor" modifications of Harvey Cushing's silver clip outfit: ${ }^{10}$ the "McKenzie clip" became, in an essentially unchanged form, what is known and used today as the hemostatic vascular clip. Another simple but enduring contribution was the perforator and ball burr design still used today with the hand-operated Hudson's brace."

An important conceptual contribution to neurosurgery was McKenzie's "point of view concerning treatment" of glioblastoma. ${ }^{12} \mathrm{He}$ condemned the then popular management by biopsy followed by external dural and bony decompression, because of the resulting deformity and "prolongation of life long after the time when death would be a relief". He advocated a radical resection of the tumor and overlying brain sufficient to slacken the intracranial contents (removing a mass "approximately the size of a small orange") but short of producing any additional neurological deficit, a procedure he termed "internal decompression", followed by a tight dural closure and replacement of the bone flap. The usual result was several months of useful existence, allowing the patient to set their affairs in order, followed by a mercifully short, terminal course when the resection cavity refilled with tumor.

McKenzie's writings,' which spanned the breadth of neurosurgery in his time, were more personal and entertaining than the scientific style of neurosurgical articles today, but were always wise, solid and honest clinical reports. He had a particular interest in spasmodic torticollis, and the operation he developed to treat this condition, known as the "McKenzie Operation"*, ${ }^{33,14}$ remains the best surgical palliation available for a miserable and still enigmatic condition. Other life-long interests were as varied as brainstem tractotomies for chronic pain, ${ }^{15.16}$ to acoustic neuroma. In 1955 Drs. McKenzie and Alexander reported a detailed review and extended follow-up of a total of 144 patients with acoustic neuroma treated at the Toronto General Hospital over an almost 30 year period. ${ }^{17}$ In typical McKenzie fashion this paper contained a step-by-step description of an organized and meticulous operative method which had resulted in an operative mortality rate of only $12.1 \%$ in the last 66 consecutive cases with complete removal. In an era when surgery in the cerebello-pontine angle was still a very serious undertaking with a high mortality, McKenzie's operation was to take the tumor out without damaging anything but the facial nerve, and his results indicate he usually did just that. $\mathrm{He}$ himself was never able to do so, but he anticipated improvements in technique which would enable the routine preservation of the seventh nerve.

\section{The McKenzie Residents}

Dr. McKenzie trained a remarkable succession of young men who went on individually to help establish and form neurosurgery in North America. After spending a year at the University of Chicago including time under Percival Bailey in neurosurgery, William S. Keith returned to Toronto in 1930 to become McKenzie's first full-year neurosurgical resident. Dr. Keith pioneered paediatric neurosurgery in Canada following an

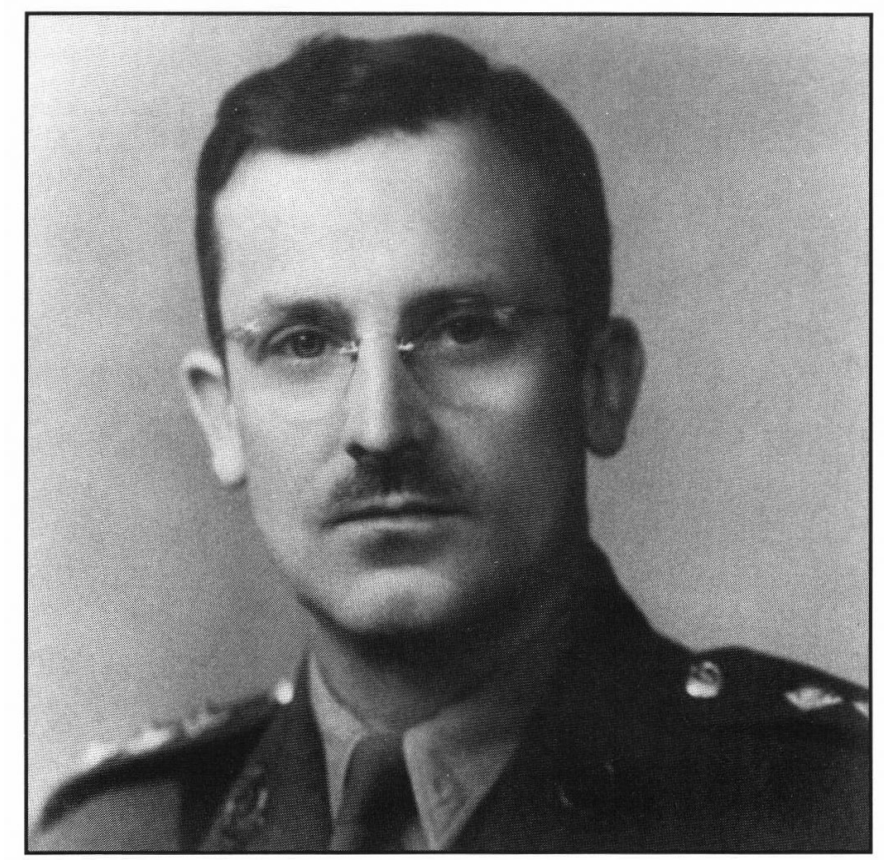

Figure 2: Dr: McKenzie's first neurosurgical trainee, Major William S. Keith, circa 1942. Dr. Keith became officer-in-charge of the Canadian Mobile Neurosurgical Unit following the allied invasion of Europe in 1944. Photograph courtesy of Dr. Ross Fleming.

appointment to Toronto's Hospital for Sick Children in 1933, and he organized an adult neurosurgical service at the Toronto Western Hospital in 1936 (Figure 2). Energetic, stimulating and kind, Bill Keith became one of Canada's most beloved neurosurgeons, ${ }^{18}$ and the annual William S. Keith Visiting Professorship in Neurosurgery, a highlight of the academic year for the University of Toronto Division of Neurosurgery was established in his honour in 1976.

In 1928 Dr. Frank Turnbull was a senior intern in medicine at Toronto General Hospital planning a career in neurology. However, after witnessing a man die from a subdural hematoma he had suspected, but upon whom his staffman would not allow surgery (insisting the diagnosis was infarction), he asked McKenzie for a transfer to neurosurgery. Dr. Turnbull became the first official entrant to Toronto's surgical "Gallie Course", and spent a year with McKenzie in 1931-32 (Figure 3). After additional training in Europe he returned in 1933 to his home city of Vancouver to introduce the specialty of neurosurgery to Canada's west coast, the story of which was the subject of a delightful Presidential Address to the Harvey Cushing Society in $1950 .{ }^{19}$ Some of Dr. Turnbull's reminiscences of his time with McKenzie are included in Eben Alexander's commemoration, ${ }^{2}$ and many others are contained in his unpublished autobiography.

A total of seven more men were trained as neurosurgeons by McKenzie. E. Harry Botterell, McKenzie's successor at Toronto General Hospital, spent a year with Dr. McKenzie over 1936-37. C. Palmer McCormick studied with Dr. McKenzie in 1942 and following World War II practiced in Toronto. William D.

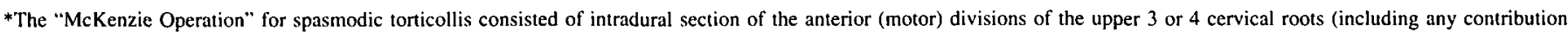
from the accessory nerve to the Ist motor cervical nerve), bilaterally, combined with either spinal accessory nerve division or more commonly a preceding sternomastoid denervation in the neck. 


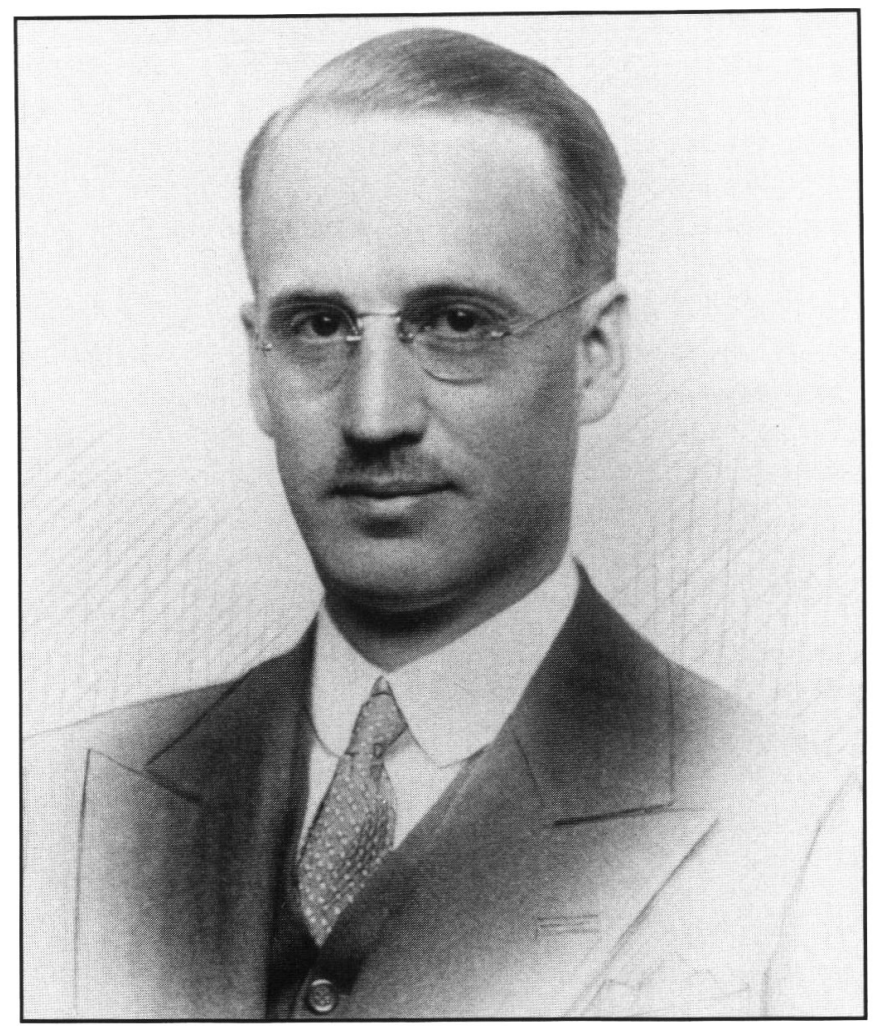

Figure 3: A portrait photograph of Dr. Kenneth G. McKenzie, given to Dr. Frank Turnbull, with the handwritten inscription (not shown): "With my sincere regards to Frank Turnbull H.S. in neurosurgery at T.G.H. during 1931-32. K.G. McKenzie. Good hunting Frank, Ken." Photograph courtesy of Dr. Frank Turnbull.

Stevenson finished the Gallie Course in 1942 and then entered the army where he received a further 6 months of neurosurgery in preparation for service overseas. After the war Stevenson, with Harry Botterell's recommendation, was accepted by McKenzie for further neurosurgical training, following which he was invited to open a neurosurgical department at Dalhousie University in Halifax in 1948. Dr. Eben Alexander, Jr. spent a six month fellowship with McKenzie in 1948 before joining the Bowman Gray School of Medicine in Winston-Salem, North Carolina. $^{2}$

Joe Cluff became interested in neurosurgery during his internship in Vancouver, and after enlisting in the army in 1943 and starting an army psychiatry course in Toronto, he introduced himself to McKenzie and began assisting nights and weekends both on the neurosurgical ward and in the operating room at Toronto General Hospital. Cluff transferred to the Neurosurgical Service at the Christie Street Department of Veteran's Affairs (D.V.A.) Hospital in 1944, and subsequently played a vital role in redeveloping neurosurgery at the D.V.A. hospital under Dr. Botterell, who took charge in 1945 after returning home from overseas. Following discharge from the army Cluff received neurosurgical training under McKenzie and Botterell, which he completed in 1949. Dr. Cluff then returned to Vancouver to join Frank Turnbull at the Vancouver General Hospital.

During his last internship rotation at Toronto General Hospital in 1945 Dr. Charles G. Drake ended up alone with McKenzie on the neurosurgical service when another resident developed a serious allergy to surgical gloves. Drake worked hard but was exhilarated by the experience. Dr. McKenzie was impressed one night in particular when young Drake was able to track him down at a formal dinner at the Royal York Hotel in order to operate on a man with a correctly diagnosed epidural hematoma. In those days, Dr. Drake recalls, the surgical list commenced with "knife to skin" at eight A.M., and commonly consisted of a "ventric" (ventriculogram), "tic" (Frazier operation) and a "tumor", in that order. Following the war and upon McKenzie's advice Drake studied neurophysiology and neuroanatomy at the University of Western Ontario (where he had attended medical school) and Yale. ${ }^{24}$ Following training in general surgery with the distinguished Angus McLaughlin in London, Ontario, Drake took 18 months of neurosurgical training with McKenzie and Botterell, finishing in 1951. After travel abroad to observe some of the great contemporary European neurosurgeons, and time in neurology at Queen Square, Dr. Drake returned to Toronto, studying neuropathology and preparing to fulfill a prior agreement to join McKenzie and Botterell in practice at Toronto General Hospital. However, the perceptive Dr. McKenzie probably recognized a certain independence in young Drake, and must have recognized the need of a neurosurgeon to serve the large and growing population in southwestern Ontario, and so advised Drake to return to the University of Western Ontario, in London, to start practice. McKenzie predicted that Dr. Drake would "blossom" more fully on his own than in the shadow of the neurosurgeons at the Toronto General Hospital, and he particularly encouraged his pupil to "have a crack" at a field he felt most promising, vascular neurosurgery (Figure 4). Dr. Drake remained very close to McKenzie, his surgical mentor, and it was even McKenzie he called when, in 1958 , he was faced with his first patient with a diagnosed ruptured basilar apex aneurysm. Drake followed McKenzie's suggestion and studied the various surgical routes to the basilar artery in several cadavers, so that when his patient, a 50-year-old farmer, suffered his second hemorrhage, and the family agreed to the risks of surgery, he was able to repair the aneurysm successfully using a subtemporal approach. ${ }^{21}$

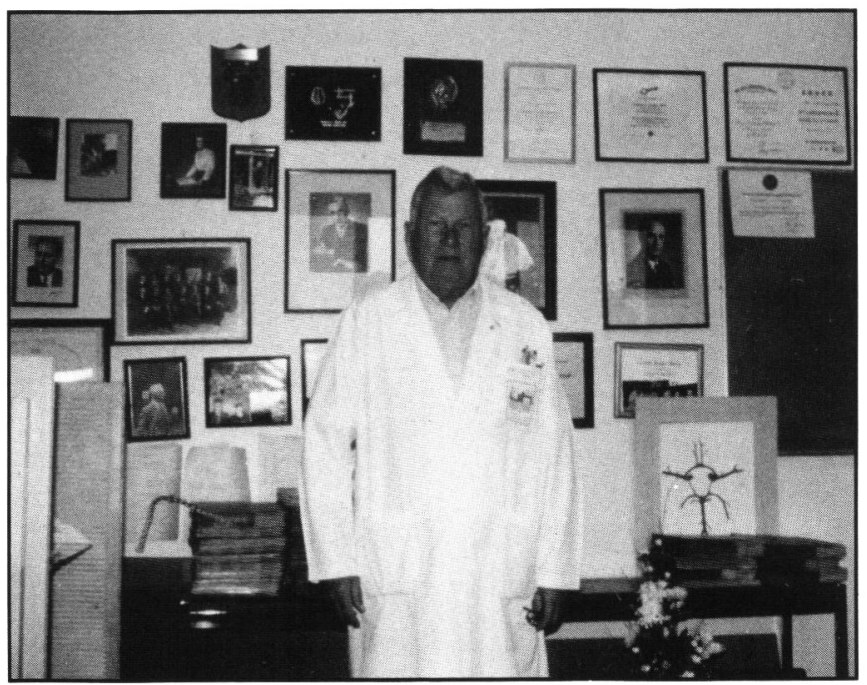

Figure 4: Dr. Charles Drake, in his office at the University Hospital in London, with photographs of his teachers McKenzie over his left shoulder, and Botterell over his right (summer, 1992). 
Dr. Charles Taylor, the son of one of McKenzie's medical school classmates, became interested in neurosurgery when he rotated through the service as a general surgical resident. Dr. Taylor tells us (personal communication, 1992):

"I remember Dr. McKenzie as a very quiet-spoken man, who listened carefully to the history and findings as presented by his resident, then asked the patient a very few pertinent questions, checked a very few of the findings described, and then stated his agreement or otherwise. I remember him once checking a plantar response I had said was upgoing. When he tried it, it flickered in a very indeterminate manner (to my dismay). Instead of disagreeing he said 'Charlie, let me see you demonstrate that plantar response'. To my immense relief when I did so it was a brisk, clear, unequivocal upgoing toe. He was surprised but in his own quiet way said nothing, except that he had to agree with my diagnosis. I always felt that little incident helped him to decide to invite me to join the residency program!"

Taylor was McKenzie's last official resident, and in 1953 he began neurosurgical practice at the Calgary General Hospital. Calgary was at that time the largest city in Canada $(165,000)$ without a dedicated neurosurgeon. In 1966 he moved to Calgary's new Foothills Hospital, and he became head of the Division of Neurosurgery several years later when the specialty became a separate division in the Department of Surgery.

Part of McKenzie's appeal was his great modesty, and refusal, in the words of one of his trainees, "to put himself forward, ever". He was not a tall man, but athletic with an athlete's build and pleasant, handsome features. He was an impulsive chain-smoker and absent-minded about mundane matters, but quietly intense in the operating room. He did not particularly enjoy speaking to an audience. Humble, honest, and a personable teacher, he made great friends of his students and colleagues around the world (Figure 5). Bill Stevenson recalls that Dr. McKenzie was also not averse to giving financial advice:

"He told me that when I had the means, I should buy some Canadian Government Annuities, which I later did, and which are providing me some income to this day!"
As a result of his training and circumstances, McKenzie was less a scientist than the eminent Dr. Wilder Penfield of the Montreal Neurological Institute (Figure 6), but McKenzie will be remembered as a shrewd clinician, a superb technician, and a "surgeon's surgeon". He served as president of the Harvey Cushing Society in 1936-37 and was president of the Society of Neurological Surgeons in 1948-49. He was a member of the founding Editorial Board for the Journal of Neurosurgery, and served as editor from 1943 to 1950. The Canadian Neurosurgical Society honoured his name with the creation, in 1973, of the annual McKenzie Prize, awarded to the best paper given by a neurosurgical resident at the annual Canadian meeting.

Dr. McKenzie died February 11, 1964, age 72, 12 years after retiring from his position as Chief of Neurosurgery at Toronto General Hospital.

\section{Edmund Harry Botterell and Further Development of the Neurosurgical Unit at Toronto General Hospital}

Dr. Ronald R. Tasker has provided a thoughtful description of the neurosurgical life and contributions of McKenzie's successor, and one of Canada's most distinguished citizens, Dr. E. Harry Botterell. ${ }^{22}$

\section{The Prewar Years}

After graduating in medicine from the University of Manitoba in 1930 at age 24, Botterell started general surgical training in Winnipeg. William Boyd, then Professor of Pathology at the University of Manitoba, had recommended that young Botterell travel east for medical studies, and he was able to do so in late 1931 to fill a sudden vacancy in internal medicine at the Montreal General Hospital under Professor Campbell Howard, where he spent an arduous but profitable year. In 1932 a job prospect at Johns Hopkins fell through, so he moved to Toronto to become a demonstrator in anatomy under Professor J.C.B. Grant (newly arrived from Winnipeg), and tutor in physiology under Dr. C.H. Best. Circumstances fortunate for Botterell had created a vacancy in Professor of

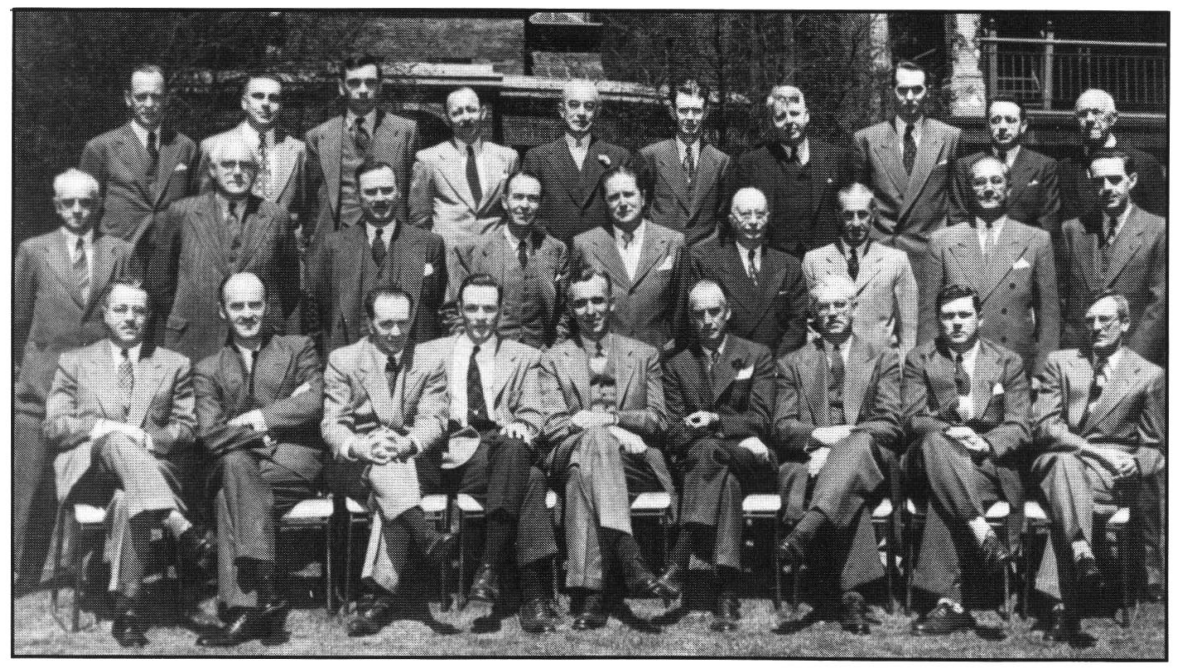

Figure 5: The "McKenzie Reunion", May 3rd, 1952, commemorating Dr. McKenzie's service as Chief of Neurosurgery at Toronto General Hospital. From left to right, FRONT ROW: Stevenson, Tumbull, Cluff, Alexander, Botterell, McKenzie, McCormick, Drake, Keith (the only McKenzie resident missing was Taylor), MIDDLE ROW: Linell, Gallie, Hyland, Spurling, Davis, Semmes, Kahn, Craig, Jousse, BACK ROW: Richardson, Smith, Scott, Walters, Harris, Wollin. Stokes, Barnett, Horsey, Shenstone. Photograph courtesy of Dr. Frank Turnbull. 


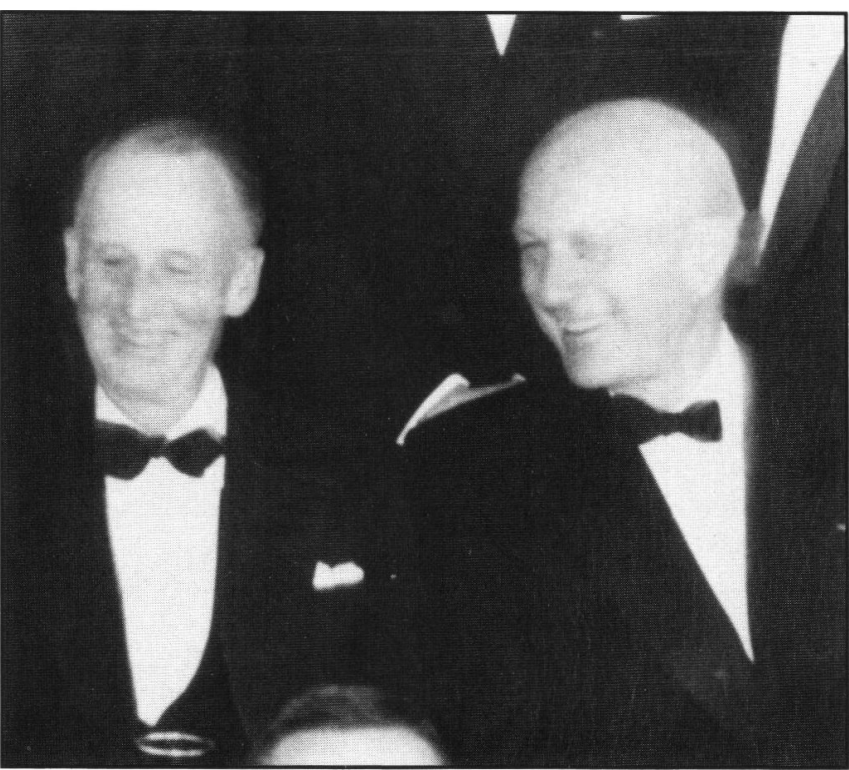

Figure 6: A rare shot of the two fathers of Canadian neurosurgery, Drs. Kenneth G. McKenzie (left), and Wilder Penfield (right), sharing a lighter moment while posing for a group photograph of the American Academy of Neurological Surgery in Toronto, November 1958. Photograph courtesy of Dr. Ross Fleming.

Surgery W.E. Gallie's Chief Resident position in 1933, and Botterell received the appointment. He became Prof. Gallie's resident surgeon at the Toronto General Hospital in 1933-34. In addition to his surgical duties that year Botterell became involved in research on fracture healing at the Banting Institute. Dr. Banting, learning of this, remarked to Botterell that "Surgeons kill more dogs, use more laboratory supplies, but never get anything done!", but in fact Botterell published a paper in Lancet based upon the work done with the biochemist Dr. Earl King that difficult year. ${ }^{23}$ Towards the end of 1934 Botterell bumped into Dr. McKenzie at a faculty lunch at Hart House and McKenzie, having learned of Botterell's qualities, suggested that Botterell join him in neurosurgery. Accepting, Botterell was immediately sent off by McKenzie for nine months of neurology at Queen Square (1934-35), followed by a year at Yale studying neurophysiology of the cerebellum in primates under Professor John Fulton. ${ }^{24-28}$ The latter laboratory had become a Mecca for young neurosurgeons of the time, learning how to operate on primates and handle brain tissue. With this background Botterell returned to the Toronto General Hospital in 1936 as a combined junior surgeon and neurosurgical trainee under McKenzie, receiving also an appointment as Lecturer in Neurophysiology under Charles Best. Botterell thus became the Toronto General Hospital's second neurosurgeon.

Professor Gallie, a generous man dedicated to supporting his young staff with new practices, made a point of sending to Botterell any of his spinal fracture patients who had associated spinal cord injuries. One of the first was a young man who was paralysed from a football injury. Botterell took on this patient, who had only a trace of cord function left, and tried carefully to prevent bladder infection by employing Munro's (a Boston neurosurgeon) new system of "tidal irrigation" of the bladder, and to prevent the development of pressure sores. The result was dramatic. At a time when such patients usually died from sepsis this patient made a remarkable recovery. The same principles were applied successfully in two more successive patients, kindling Botterell's career-long interest in improving the care of paraplegic patients.

\section{The War Years}

With World War II Botterell enlisted in the Royal Canadian Army Medical Corps, and went overseas in 1940, along with Professor Colin Russel and William Cone of the Montreal Neurological Institute, as part of the advance party for the all Canadian No. 1 Neurological Hospital (which later became the Neurological and Plastic Surgery Hospital), which was set up in Basingstoke, England. He served at Basingstoke between 1940 and 1945, rising to the position of Officer-in-Charge, Neurosurgery, with the rank of lieutenant-colonel (Figure 7). During this five year period McKenzie was left to care for the busy neurosurgical service at Toronto General Hospital alone.

While in England Botterell visited Geoffrey Jefferson in Manchester and ended up running the neurosurgical service there for a month while Sir Geoffrey Jefferson was away on emergency medical service for the government. Botterell enjoyed his experience in Manchester, and was deeply influenced by the eminent Sir Geoffrey Jefferson, then the doyen of British neurosurgery. ${ }^{29}$

\section{Lyndhurst Lodge}

When Botterell returned from overseas in 1945 he found, in his own words, many of the spinal cord-injury patients from the war, some who had gone through his service at Basingstoke, "lying around rotting" at the Christie Street Department of Veteran Affairs Hospital in Toronto. He decided he could not immediately retire from the army to return to his civilian practice at Toronto General Hospital, which would absorb all of his energies, but he would have to remain in the army long enough to assist in the plight of these pitiable patients, and straighten out in particular the problem of the young veteran paraplegic patients.

Botterell realized that it was necessary to hire a full-time physician to provide comprehensive and ongoing medical care for the paraplegic patients at the Christie Street Hospital and

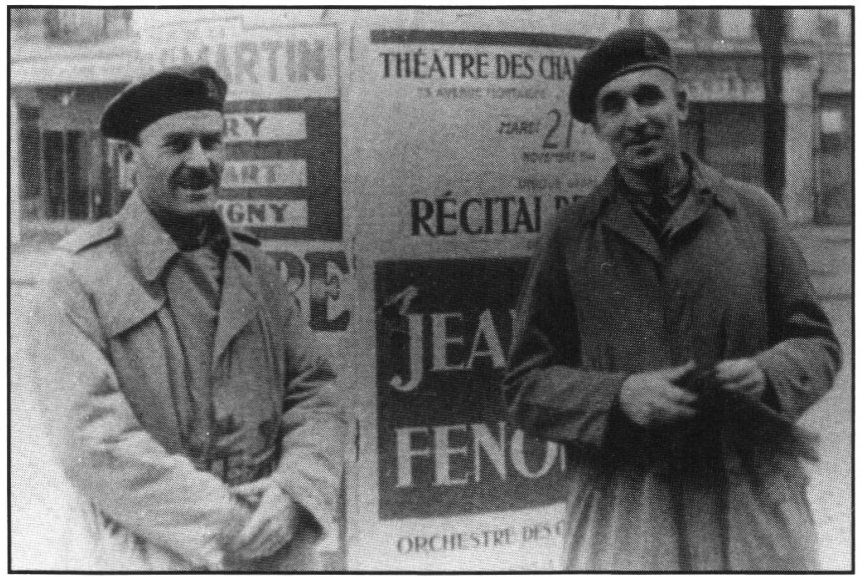

Figure 7: Lieutenant-colonel Harry Botterell (right) with Major Frank Turnbull (Royal Canadian Army Medical Corps) in Paris. The poster in the immediate background between the two men indicates the date: November 21. 1944. Photograph taken by Lieutenamt-colonel Edgar Kahn (United States Army Medical Corps), and courtesy of Dr. Frank Turnbull. 
affiliated Lyndhurst Lodge for paraplegic patients. McKenzie told Botterell just the man for the job, Dr. Albin T. Jousse. Jousse had assisted McKenzie during the short-staffed war years, teaching medical students and examining and working up patients in preparation for surgery. Unfortunately, Jousse was preparing to take a job as an internist in Sudbury. Harry Botterell immediately contacted and interviewed Jousse, offered him a position which had no precedent, hadn't any funding yet, and for which Jousse would have to withdraw from his commitment to Sudbury, and asked him to think about it for a few days. In typical Botterell fashion, he phoned Dr. Jousse several hours later and asked him what his decision was. Even the few hours were probably not necessary, however, since the response was an immediate acceptance. Dr. Jousse, who had been medically unfit for military service, felt that this might be a worthy "war effort" he was capable of, and in 1945 he was appointed Medical Director to the first hospital dedicated to the rehabilitation of spinal cord injured patients in North America, Lyndhurst Lodge (Figure 8).

At that time the methods to keep paraplegic patients alive were becoming known, and were employed at Lyndhurst: tidal irrigation of the bladder, regular bowel evacuation, antibiotics for sepsis, chest physiotherapy for the higher cord lesions, and prevention of pressure sores by a motivated group of nurses and orderlies. But for Drs. Botterell and Jousse, mere survival after a spinal cord injury soon became the easiest part. Dr. Jousse has said (personal communication):

"... it became clear to us that we were not saving them for much of a life to look forward to: to send these young fellows home to live in bed, or get pressure sores and die, or have recurrent urologic infections that the local doctor might not know how to treat. You had to educate them and get them in wheelchairs and get them active ... to make them self-sufficient so that they could live independently with a vocation ... in society as productive citizens."

Then, and in later years, Dr. Jousse himself was a great inspiration to his patients. Dr. Jousse is stricken with a slowly progressive spinal cord degenerative disease, the nature of which

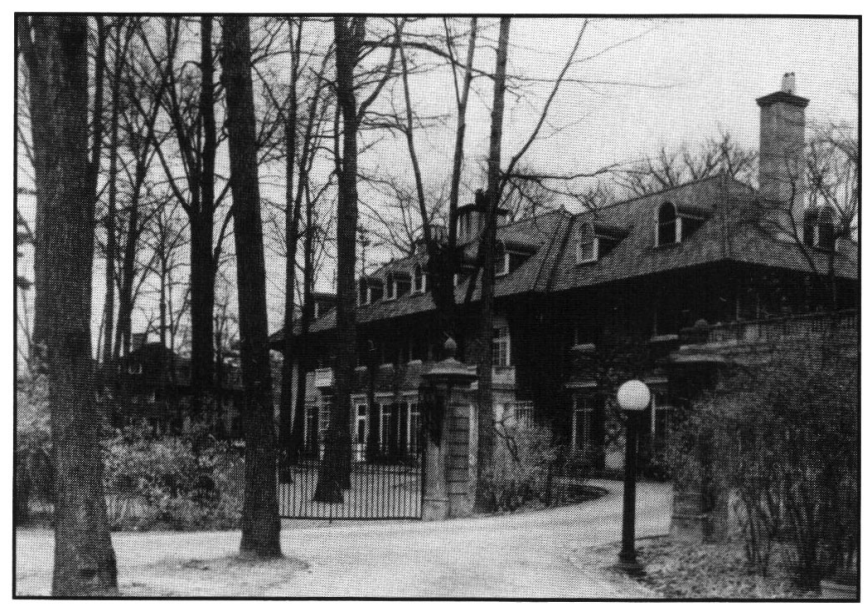

Figure 8: Lyndhurst Lodge, the original house that was converted into the first institution dedicated to the rehabilitation of spinal cord injured patients in North America, on Lyndhurst Avenue near the corner of Bathurst Street and St. Clair Avenue in Toronto. Photograph courtesy of Dr. Albin Jousse. has never been established with certainty, but with unflinching commitment and endurance, on canes and then crutches, Dr. Jousse not only provided personal medical care to hundreds of para- and quadriplegic patients, but also revolutionalized the rehabilitation of these disabled individuals. ${ }^{30}$

\section{The Postwar Years, and Introduction of Neuroradiology to Toronto General Hospital}

After honing his organizational and administrative skills at Basingstoke and with veteran medical affairs back in Canada, Botterell returned to full-time neurosurgical practice at the Toronto General Hospital in the fall of 1945, at age 39. Interested in updating the neurosurgical service, one of his first jobs was convincing McKenzie of the need of a neuroradiologist, since McKenzie was not reliant on anyone in the interpretation of $\mathrm{x}$-rays. Dr. Douglas C. Eaglesham had worked with Arthur Childe, Canada's first specialist in neuroradiology from the Montreal Neurological Institute, at Basingstoke, and when appointed in 1945 he raised the whole standard of neuroradiological diagnosis at the Toronto General Hospital. In 1948, when Eaglesham left to start practice in Guelph, Ontario, he was succeeded by Dr. Delbert G. Wollin who had also served for a short period at Basingstoke as a radiologist, but who studied neuroradiology from Dr. Donald McRae after the war at Montreal Neurological Institute. Wollin was the neuroradiologist at the Toronto General Hospital until 1959, when he left for a position in Calgary. He was then replaced with another trainee from the Montreal Neurological Institute, Dr. George Wortzman.

Delbert Wollin remembers the pneumoencephalograms, which were brutal experiences for the patient, and the somewhat less stressful ventriculograms, in those early years, where cerebrospinal fluid was drained and air injected in the operating room by residents and the patient then transported to the $x$-ray department. At Botterell's insistence carotid angiography became more common, performed by direct arterial puncture with a steel needle, usually by either a neurosurgical or neurological resident, and Wollin would help analyze the films. It was decades before the introduction of catheter angiography, and in those early years no one was opacifying the posterior circulation.

Wollin recalls (personal communication, 1992):

"The neurosurgical D.O.R. became a famous place not only structurally and scientifically, but socially as well. Harry would sit there with a cup of coffee while his residents were operating. God help them if they did not tell him if they got into trouble. But he did not interfere with them, and Dr. McKenzie didn't either. It was quite a contrast from my own training where it sometimes seemed that the neurosurgery residents might come and go but never turn a bone flap. At the General Hospital the residents were given the responsibility, with very careful supervision, of treating brain tumors, herniated discs and all this sort of stuff. Harry Botterell worked the residents right into the ground. They learned a lot and became accomplished neurosurgeons. Above all he was a great teacher; he had a great knack for teaching, a certain showmanship at rounds, that made his rounds very memorable. Another thing he did that was very helpful for me was to call me to the operating room for every tumor after he had it exposed so that I could see exactly where the tumor was, and how it correlated with the $\mathrm{x}$-rays. Although it meant a lot of running it was worth it. That clinical and anatomical 
liaison doesn't exist anymore for radiologists. He took that time and no one else did before or since. Harry was basically a teacher."

Neurosurgical trainees were Assistant Residents for 6 months followed by usually 18 months in the Chief Resident position: the Chiefs continued until they were felt by Drs. McKenzie and Botterell to be competent neurosurgeons. In 1952 Botterell succeeded Dr. McKenzie, then age 60, as Head of the Division of Neurosurgery. His first of eight chief residents was Dr. William J. Horsey, who became the first dedicated neurosurgeon at St. Michael's Hospital, Toronto. In the years that followed, Dr. Horsey's skill as a surgeon and teacher, combined with his stamina and dedication to his hospital, established St. Michael's as one of Canada's leading neurosurgical centers. ${ }^{31}$

The second Botterell resident was Dr. William M. Lougheed, who during his general surgical training with Drs. Gordon Murray and Bill Bigelow, early vascular and cardiac surgeons at Toronto General Hospital, had developed a particular interest in vascular disease.

\section{The Early Development of Vascular Neurosurgery at Toronto General Hospital}

During his time in England Botterell had decided that no neurosurgeon in his time would be much better than Cushing or McKenzie operating on brain tumors, which he looked at (in the case of malignant neoplasms) as surgically insoluble and basically biological problems. On the other hand, a successful cerebrovascular operation left the patient cured. So, despite the great difficulties and often discouraging surgical results at the time for vascular lesions of the brain, Botterell committed himself to the development of cerebrovascular surgery at the Toronto General Hospital.

In part, this early surgical interest in cerebrovascular disease, and cerebral aneurysms especially, was made possible by the neurologists at the Toronto General Hospital, and their increasing willingness to share these patients with the surgeons. Dr. $\mathrm{H}$. Hyland and his younger associate J.C. Richardson had done pioneering work on the subject of aneurysms. Dr. John Clifford ("Ric") Richardson had specialized in neurology at Queen Square before the war, following which he returned to the Banting Institute as a fellow under Prof. Eric Linell. It was during this time he carried out a detailed clinicopathological study of aneurysmal subarachnoid hemorrhage with Herbert Hyland that became the basis of a widely cited paper in 1941.32 After serving as officer-in-charge of the neurological division of the No. 1 Neurological and Plastic Surgical Hospital in Basingstoke in World War II, Richardson returned to his neurological practice at the Toronto General Hospital. Here he maintained both an active interest in cerebrovascular disease and the important clinical link established with his neurosurgical colleagues during the war.

In 1952 Lougheed went to Boston to work in Dr. William H. Sweet's laboratory. Inspired by the work of Bill Bigelow, who had introduced the concept and technique of hypothermia for open heart surgery, Lougheed established a method of hypothermia and reversible cerebral circulatory arrest for neurosurgery. ${ }^{33.34}$ Lougheed returned to Toronto in 1954, and along with anaesthetist Dr. Stuart L. Vandewater and clinical neurophysiologist Dr. John W. Scott, Botterell and Lougheed commenced hypothermia and temporary cerebral circulatory arrest for aneurysm surgery almost immediately (Figure 9). The detailed report of this method in Botterell's first 22 patients with ruptured intracranial aneurysms which was published in $1956^{35}$ opened a new era in aneurysm surgery. The surgical procedure that provided exposure for temporary occlusion of the cervical cerebral arteries as well as intracranial exposure of the aneurysm was demanding, and the anaesthesia, temperature control and cardiac monitoring no less so. Stuart Vandewater recalls (personal communication, 1992):

"Something that is not generally known is that anaesthesia for neurosurgery in those days and for some time to come was largely ether, and since fire and explosion was always a hazard the drapes were always wet. I decided that I was not going to use ether. While in Edinburgh I had been introduced to an old but nonflammable anaesthetic, chloroform, which we used for the aneurysm cases until halothane was available. The patient would arrive very early and I would put them in a quiet cool room and drip in the "lytic cocktail" (largactil, phenergan and demerol) we had developed. After the patients were asleep we connected all of the monitoring gear, put them on the anaesthetic machine and moved them into the ice tank. Since there were no ventilators at that time we maintained light anaesthesia to allow spontaneous respirations; it was simply not possible to ventilate the patient by hand for the whole case. There was a lot of debate then about the disadvantages and possible merit of $\mathrm{CO}_{2}$ retention: brain swelling and arterial dilatation and so forth. The technique of arterial lines and of doing arterial blood gases were still in their infancy, but we would send a runner with a syringe full of blood across the street to somebody's lab in the Banting who was experimenting in blood gases, but the results were quite unreliable. You were there by yourself, doing something nobody had done before, running the ice and temperature and electrocardiogram and taking blood samples and flushing out the needle, but there was a continuous stream of visitors and everybody was enthusiastic and always rose to the challenge."

This paper is also remembered for grading patients with varying severities of subarachnoid hemorrhage, the first such grading system of its kind, the "Botterell Scale". Within ten years hypothermia for aneurysm surgery would largely be replaced, for routine aneurysm surgery, by controlled hypotension to facilitate aneurysm clipping in the event of intraoperative rupture, but at the time this work brought the Toronto General Hospital to the very forefront of the emerging field of vascular neurosurgery.

Dr. John W. Scott, a clinical neurophysiologist, became an important link between neurosurgery, neurology and basic physiology at the University of Toronto. In 1949 he was appointed to both the Departments of Medicine and Surgery of the Toronto General Hospital to establish a unique Clinical Neurophysiology Service for both the Divisions of Neurology and Neurosurgery. He became the hospital's electroencephalographer and electromyographer. He received, as well, an appointment to the University Department of Physiology under Dr. Charles Best. Dr. Scott's subsequent academic career did not interfere with his clinical liaisons, but rather enabled him to make valued scientific contributions to the neurosurgical activities at the Toronto General Hospital. His clinical neurophysiology laboratory immediately neighbored the neurosurgical D.O.R., and he stimulated neurosurgical conversations and rounds with current advances in basic and general science. Scott's counsel was 


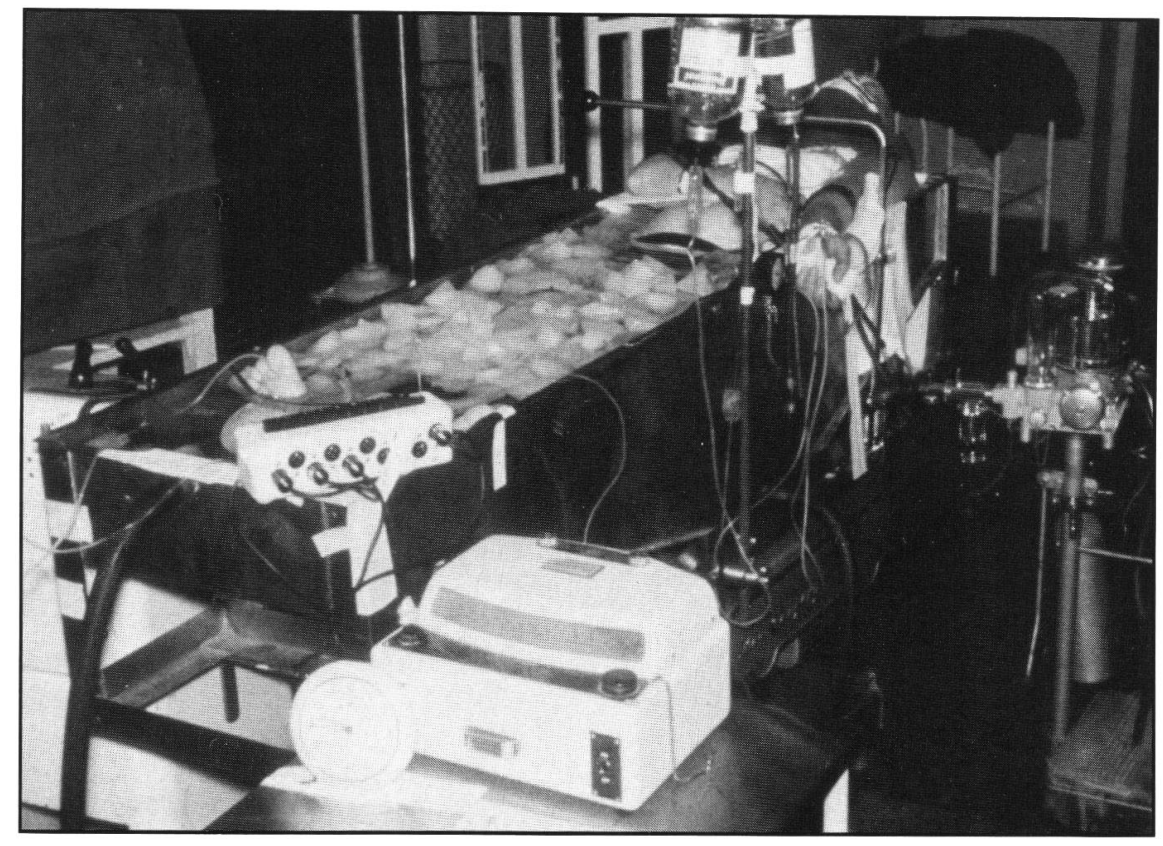

Figure 9: An aneurysm patient immersed in an ice-water bath for induction of hypothermia and preparation for craniotomy, a left radial arterial line inserted. Photograph courtesy of Dr. Stuart Vandewater.

often sought and always helpful to his neurosurgical associates, and he even enabled Botterell to resect the occasional epileptic temporal lobe under proper electrocortigraphic control.

\section{The Opening of a New Neurosurgical Unit at the Toronto General Hospital}

McKenzie had decided early on that neurosurgery belonged in the midst of a general, university affiliated hospital, rather than a separate institution, and in this Botterell supported him unreservedly. Both men had fostered establishment of neurosurgery divisions at the other general teaching hospitals associated with the University of Toronto. At the Toronto General Hospital itself, however, a dream that began with McKenzie and realized under the direction, planning and extraordinarily strong leadership of Botterell, was the opening of a new neurosurgical "unit" in a new Center Block of the hospital.* This model unit, consisting of new neurosurgical operating rooms on the second floor, offices on the eleventh floor and patient rooms (including an "intensive treatment room") on the twelfth floor, was occupied in 1957. The official opening was on November 8, 1958, the occasion coinciding with the time Toronto hosted the twentieth meeting of the American Academy of Neurological Surgery.

$A$ unique and special feature of the new unit were mural paintings filling the walls of the twelfth floor waiting room, executed by Charles Fraser Comfort, then the President of the Royal Canadian Academy of Arts and a professor in the Department of Art and Archaeology at the University of Toronto. In these handsome, well-researched paintings, the artist, in his own words, "has paid tribute to medical scholars of the classical and Renaissance periods and commemorated the contribution of modern neurosurgery in its treatment of injuries and disorders of the human brain". ${ }^{36}$ The names included in these murals are those of men of unquestioned rank in the development of neurosurgery (Figure 10). Fixed to concrete and too costly to move, these paintings have proven more durable than the unit they celebrated, and still dwell on the twelfth floor of the Norman Urquhart Building, a reminder of a different time.

\section{Jessie Young, R.N. and Neurosurgical Nursing at the Toronto General Hospital}

Jessie Young had a great thirst for knowledge and a great aptitude for teaching. She attended the University of Toronto after nursing school, and after serving in England during World War II she taught nursing in Toronto. After several years she moved to San Francisco where she worked as a nurse part-time and took courses at university at night. After obtaining her Bachelor of Arts she returned to the Toronto General Hospital in the early 1950's, working on the surgical wards. One morning Dr. Botterell ran into her and announced that she was just the person he had been looking for. He took her to his office and asked her to take charge of nursing care and teaching on the new neurosurgical unit he was opening. Jessie hesitated, since she had not had a completely enjoyable time in neurosurgery as a student. She recalls (personal communication, 1992):

"I wasn't sold on neurosurgery since I remembered, years before, as a student, the patients mainly all died. I recall in particular we had a poor little 7-year-old girl a tumor, who I had nursed after surgery, and who died, and I had been very upset. We just didn't know what to watch for in the neurosurgical patients. Even then in the 50's, when Dr. Botterell came to me with his suggestion, we (the nurses) just took vital signs and did not look at responsiveness or eyes at all." However, Botterell explained that he would want the person in that position to be well prepared to open the best neurosurgical unit in the world, and it was his promise of a tour of outstanding 


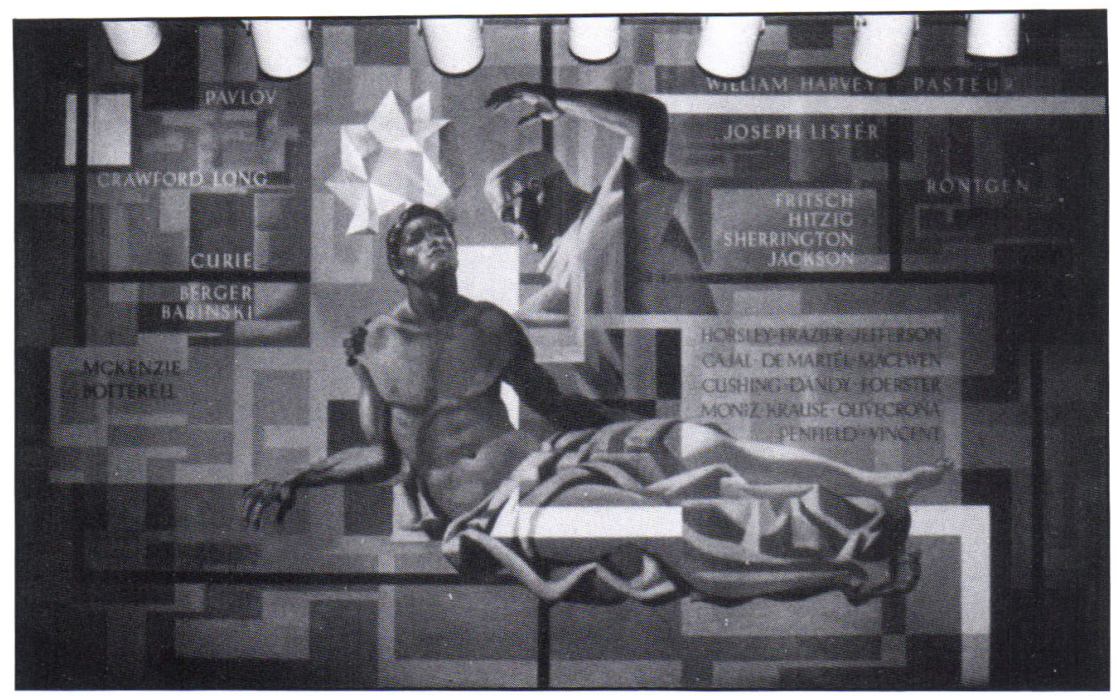

Figure 10: The mural painting on the north wall of the waiting room of the "new" neurosurgical unit at the Toronto General Hospital, on the twelfth floor of the Norman Urquhart Building. This particular panel acknowledges the contribution of neurosurgeons since this branch of surgery became a separate specialty under the guidance of Sir Victor Horsley about 1890. In the words of the artist, Mr. Charles Comfort. "The reclining male figure symbolizes humanity in the broadest sense. Lending support to this figure is a neurosurgeon, his left arm raised in a strong but compassionate gesture. Above the head of the reclining figure is a crystalline form, symbolizing the restoration of mental perception and spiritual clarity ... (on either side) of the figure of Humanity appear the names of some of the distinguished neurosurgeons whose knowledge and skill have made possible the extraordinary advances in the field within the period stated ... In the upper areas of the painting appear the names of some scientists and scholars, other than neurosurgeons, whose theories and discoveries have contributed vitally to the great advances that have been made in neurosurgical practice since Lord Lister published his paper, The Antiseptic Principle of the Practice of surgery, in 1867."

neurosurgical centers in North America and abroad that won him the services of Ms. Young. She visited the great neurosurgical units in Montreal, Boston, New York, London, Stockholm, Copenhagen and Switzerland. Jessie Young came back to the Toronto General Hospital inspired and devoted herself to the development and teaching of neurosurgical nursing.

During her travels she had still not found a good system for nurses to monitor patient's neurological status, and one remarkable achievement soon after taking her position was creation of a nursing routine which systematically charted the patients level of consciousness, movement and pupillary responses, in addition to vital signs. Dubbed the "McKenzie Routine" in honour of then retired Dr. McKenzie, this prescient system was in use for years at the Toronto General Hospital (although never reported in the literature!) prior to the global introduction of the popular and remarkably similar Glasgow Coma Scale.

Inspired by a formal association of neurosurgical nurses recently established in the United States, in 1969 Ms. Jessie Young founded the Canadian Association of Neurological and Neurosurgical Nurses (CANN), and served as its first President. In 1983 The Jessie Young Bursary was established, which is awarded annually. Innovative, loyal, compassionate, and above all dedicated to teaching, Ms. Jessie Young was role model to several generations of nurses that staffed the neurosurgical wards at the Toronto General Hospital and neurosurgical units of hospitals throughout Canada.

\section{Botterell's Contributions to Neurosurgery, and the Botterell Residents}

Harry Botterell's many neurosurgical writings ${ }^{37-70}$ included discussions of brain and spinal injury, management of cerebral aneurysms and subarachnoid hemorrhage, and radioactive tracer localization of brain tumors. As Chief of neurosurgery in Toronto he was an aggressive and excellent administrator, with a clear vision of how to better things and the enormous energy to "get the job done". A tall, imposing individual, with a rich, forceful, and commanding voice, he had (and has) more than most the presence of a neurosurgeon. He was an accomplished and bold surgeon. By all accounts he was a very hard taskmaster, often asking the impossible of his residents, and usually getting it. However, it was apparent to all that he was no harder on his trainees than he was to himself. Patient care was always his priority. He was by nature impatient, and according to some sometimes difficult to assist in the operating room. At least one of his residents took to putting folded newspapers into his socks when assisting Dr. Botterell, in order to protect his vulnerable shins in the event that the Chief felt he was not concentrating on his task sufficiently. But above all, Botterell was a teacher.

Ronald Tasker has written: ${ }^{22}$

"The education and training of his residents who have subsequently molded neurosurgery in many parts of the world was, I think, his greatest priority. All his residents were, to Harry, special people. He often remarked upon the difficult phenomenon that every current Resident was the best he had ever had."

Harry Botterell reflects (personal communication, 1992):

"The best thing that we did was train residents because they were so much better than we were. One of our residents, who went to Hamilton, had just started practice when he brought us an angiogram that had picked up a supraclinoid aneurysm. We agreed that the patient should have it repaired, and, thinking that he might be asking, in his own way, for help I asked 'Do you want me to come over and be your assistant?' And he said 'No thanks!', as easily as that. That is the moral, you see: when they left us they were able to do neurosurgery, without our help. Not just know it but do it." 
Indeed, a characteristic of the Toronto neurosurgical training program from its inception was a commitment to produce graduates fully competent in all aspects of general neurosurgery, capable of single-handedly establishing new neurosurgical services across the nation. These young surgeons also learned the value of collaboration between the neuroscience disciplines, an effort which was pioneered at the Toronto General Hospital. Drs. Botterell and Richardson established "combined rounds", which quickly became a weekly obligation for every member of the staff at all levels in neurosurgery, neurology, neuropathology and neuroradiology. Each section played a major role in every Tuesday morning session.

Following Horsey and then Lougheed, the next Botterell resident was Dr. E. Bruce Hendrick, who after travelling to Boston for a two year fellowship in paediatric neurosurgery under Drs. Franc Ingraham and Donald Matson, returned to Toronto in 1955 to begin neurosurgical practice with Bill Keith at both the Hospital for Sick Children and the Toronto Western Hospital. In 1964, when Dr. Keith retired from the Hospital for Sick Children, Hendrick gave up his adult practice at the Toronto Western Hospital, and in so doing became the first full-time paediatric neurosurgeon in the world. ${ }^{71,72}$

Dr. Ross Fleming finished his neurosurgical residency under Botterell in 1956, having spent a cherished part of his training at the University of Michigan in Ann Arbor with Professor Elizabeth C. Crosby in neuroanatomy and Edgar A. Kahn and Richard C. Schneider in neurosurgery. Dr. Kahn had close ties to Toronto, being a friend and colleague of McKenzie and Botterell's. Fleming also studied neurology in England (Queen
Square and Oxford) and stereotaxy in Sweden, France and Germany. Fleming joined Drs. Keith and Hendrick at the Toronto Western Hospital in 1956. Dr. Fleming became Head of that Division in 1965, and in addition to his constant dedication to teaching, ${ }^{*}$ he built a large clinical and investigative neurosurgery unit at the Toronto Western Hospital.

Dr. Robert F. Hetherington, a Rhodes Scholar (Ontario 1950, Queen's College, Oxford, D.Phil., 1953), finished his neurosurgical training at Toronto General Hospital under Botterell in 1957. He became the first neurosurgeon in Kingston, Ontario, in 1958, when he created a Division of Neurosurgery at Queen's University.

Dr. Ronald R. Tasker completed his neurosurgical training in 1959, following which he obtained a six month McLaughlin Travelling Fellowship to visit the major European neurosurgical centers and in particular those surgeons doing stereotactic surgery. These included Professors Leksell in Stockholm, Talairach in Paris, Guiot at Suresne, and Riechert and Hassler at Freiberg. He then moved to the laboratory of Neurophysiology at the University of Wisconsin and worked under Professor Clinton Woolsey on a project that involved the then new technique of microelectrode recording of neuronal activity. These experiences influenced the rest of his career. On his return to join the staff at the Toronto General Hospital in 1961, Tasker focused his attention on stereotactic neurosurgery.

Drs. James K. Murray and Stanley W. Schatz both finished their neurosurgical training at the Toronto General Hospital in 1961, the former opening a neurosurgical practice in Hamilton, and the latter joining Dr. Bill Horsey at St. Michael's Hospital (Figure 11).

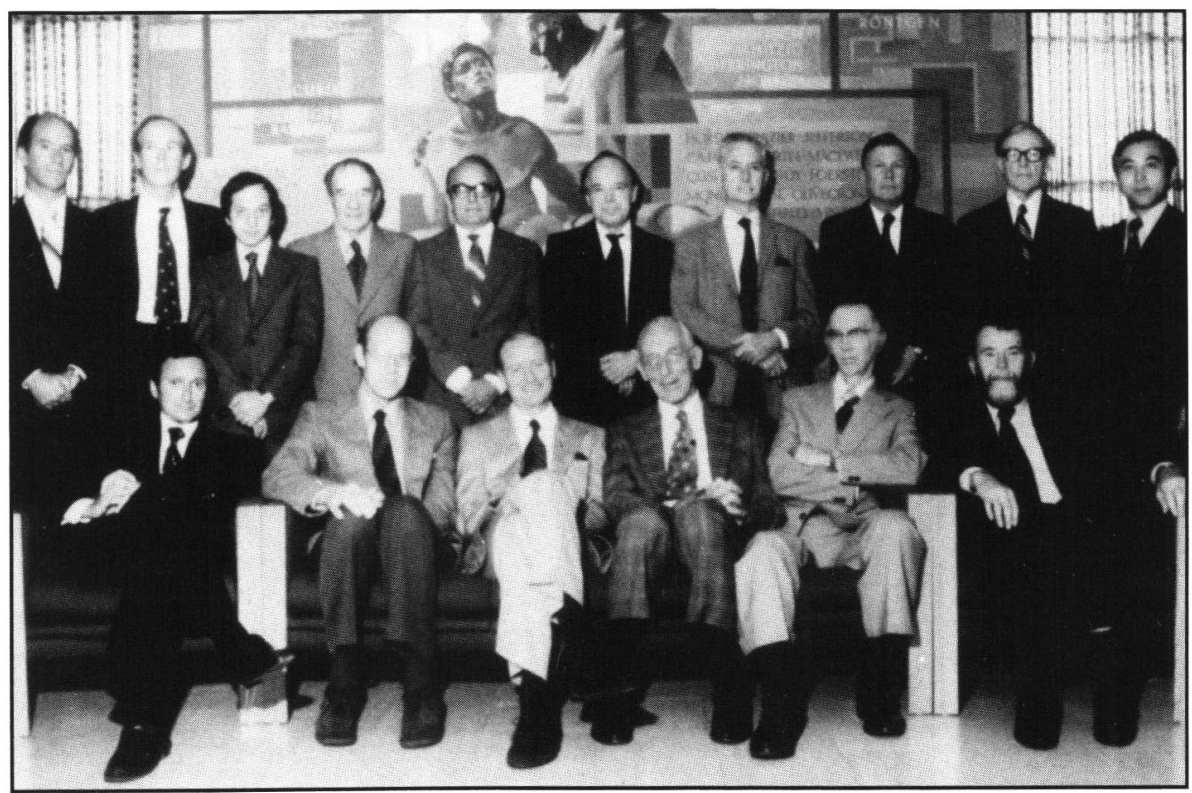

Figure 11: "E. Harry Botterell Day," Toronto General Hospital, October 12th, 1978, brought together many of Dr. Botterell's former residents and colleagues. From left to right, FRONT ROW: Hoffman, Fleming, Schatz, Botterell, Taylor, Tasker, BACK ROW: Turnbull, Morley, Francoeur, Cluff, Horsey, Lougheed, Sweet, Drake, Alexander, Yamanda. The missing Botterell residents are Hendrick, Hetherington and Murray. Photograph courtesy of Dr. Ross Fleming.

\footnotetext{
*One of Dr. Ross Fleming's persistent interests has been medical education at all levels, and he became Assistant Dean (undergraduate medical education) of the University of Toronto Faculty of Medicine in 1986. His contribution to education has been recognized by the establishment of the "Ross Fleming Surgical Educator Award" presented annually for excellence in undergraduate or postgraduate teaching.
} 
A difficult decision for Botterell was the acceptance of the position of Dean of Medicine at Queen's University in 1962. His distinguished career strengthening the Queen's medical school and as special consultant to the Ontario Medical Association, Royal College and various governments has been summarized by Tasker, as have the many honours that have come his way. ${ }^{22}$ The annual E. Harry Botterell Visiting Professorship in Neurosurgery was established in 1982 at the Toronto General Hospital in recognition of this outstanding neurosurgeon, medical educator and Canadian.

\section{REFERENCES}

1. Botterell EH. Kenneth George McKenzie, M.D., F.R.C.S. 1892 1963. Surg Neurol 1982; 17: 81-89.

2. Alexander Jr. E. Kenneth George McKenzie, Canada's first neurosurgeon. J Neurosurg 1974; 4142: 1-9.

3. Morley TP. (ed.) The Opening of the Neurosurgical Unit Toronto General Hospital November 8, 1958. University of Toronto Press 1960; page 25, Toronto.

4. McKenzie KG. In Memoriam: Harvey Cushing, 1869-1939. Am J Psychiatry 1940; 96: 1001-1007

5. Morley TP. (ed.) The Opening of the Neurosurgical Unit Toronto General Hospital November 8, 1958. University of Toronto Press 1960; pages 28-29, Toronto.

6. Richardson JCR. Herbert Hylton Hyland. Can J Neurol Sci 1978; S: 51 .

7. Morley TP. Kenneth George McKenzie. History of the Congress of Neurological Surgeons (CNS publication) 1978; 11-12.

8. McKenzie KG. The surgical treatment of trigeminal neuralgia. Can Med Assoc J 1925; 15: 1119-1124.

9. McKenzie KG. The treatment of abscess of the brain. Arch Surg 1929; 18: 1594-1620.

10. McKenzie KG. Some minor modifications of Harvey Cushing's silver clip outfit. Surg Gynecol Obstet 1927; 45: 549-550.

11. McKenzie KG. A perforator and ball burr. J Neurosurg 1944; 1 : 58-59.

12. McKenzie KG. Glioblastoma - a point of view concerning treatment. Arch Neurol Psychiatry 1936; 36: 542-546.

13. McKenzie KG. Intrameningeal division of the spinal accessory and roots of the upper cervical nerves for the treatment of spasmodic torticollis. Surg Gynecol Obstet 1924; 39: 8-10.

14. McKenzie KG. The surgical treatment of spasmodic torticollis. Clin Neurosurg 1955; 2: 37-43.

15. Drake CG, McKenzie KG. Mesencephalic tractotomy for pain. J Neurosurg 1953; 10: 457-462.

16. McKenzie KG. Trigeminal tractotomy. Clin Neurosurg 1955; 2: 50-69.

17. McKenzie KG. Acoustic neuroma. Clin Neurosurg 1955; 2: 2136.

18. Fleming R. In Memorium: William Strathearn Keith (1902-1987) Can J Neurol Sci 1988; 15: 165-166.

19. Turnbull F. Neurosurgery is what you make it. J Neurosurg 1950 7:289-293.

20. Peerless SJ. Charles George Drake. History of the Congress of Neurological Surgeons (CNS publication) 1978; 129-131.

21. Drake CG. Bleeding aneurysms of the basilar artery. J Neurosurg 1961; 18: 230-238

22. Tasker RR. E. Harry Botterell. Surg Neurol 1984; 21: 215-217.

23. Botterell EH, King EJ. Phosphatase in fractures. Lancet 1935; 1: 1267-1270.

24. Botterell EH, Fulton JF. Relations of cerebrum to cerebellum: function of paleo- and neo-cerebellum in chimpanzees and monkeys. Trans Am Neurol Assoc 1936; 62: 172.

25. Walker AE, Botterell EH. Syndrome of superior cerebellar peduncle in monkey. Brain 1937; 60: 329-353.

26. Botterell EH, Fulton JF. Functional localization in cerebellum of primates: unilateral section of peduncles. J Comp Neurol 1938; 69: 31-46.

27. Botterell EH, Fulton JF. Functional localization in cerebellum of primates: lesions of midline structures (vermis) and deep nuclei. J Comp Neurol 1938; 69: 47-62
28. Botterell EH, Fulton JF. Functional localization in cerebellum of primates: lesions of hemispheres neocerebellum. J Comp Neurol $1938 ; 69: 63-87$

29. Botterell EH. Obituary: Sir Geoffrey Jefferson. J Neurosurg 18: 407-409, 1961.

30. Botterell EH. Albin T. Jousse, medallist of the International Medical Society of Paraplegia - a profile. Paraplegia 1988; 26: 369-370.

31. Findlay JM, Tucker WS. William John Horsey, M.D., F.R.C.S.(C): neurosurgeon to St. Michael's Hospital. Can J Neurol Sci, 1993; 20: 254-255.

32. Richardson JC, Hyland HH. Intracranial aneurysms - a clinical and pathological study of subarachnoid hemorrhage caused by berry aneurysms. Medicine 1941; 20: 1-83.

33. Lougheed WM, Khan DS. Circumvention of anoxia during arrest of cerebral circulation for intracranial surgery. J Neurosurg 1955 ; 12: 226-239.

34. Lougheed WM, Sweet WH, White JC, Brewster WB. The use of hypothermia in surgical treatment of cerebral vascular lesions. A preliminary report. J Neurosurg 1955; 12: 240-255.

35. Botterell EH, Lougheed WM, Scott JW, Vandewater SL. Hypothermia and interruption of carotid and vertebral circulation in the surgical management of intracranial aneurysms. J Neurosurg 1956; 13: 1-42.

36. Morley TP. (ed.) The Opening of the Neurosurgical Unit Toronto General Hospital November 8, 1958. University of Toronto Press 1960; 2-3. Toronto.

37. Hyland HH, Botterell EH. Frontal lobe tumors: clinical and physiological study. Can Med Assoc J 1937; 37: 530-540.

38. Botterell EH, Carmichael EA, Cone WV. Sulphanilamide and sulphapyridine in experimental cerebral wounds. J Neurol Psychiatry 1941; 4: 163-174.

39. McKenzie KG, Botterell EH. Common neurological syndromes produced by pressure from extrusion of intervertebral disc. Can Med Assoc J 1942; 46: 424-435.

40. Botterell EH, Jefferson G. Treatment of scalp wounds in air-raid and other casualties. Br Med J 1942; 1: 781-783.

41. Botterell EH, Jefferson G. Tratamiento de las heridas del cuero cabelludo otras, ocasionadas en las incursiones arelas. Rev San Mil Buenos Ares 1943; 42: 223-232.

42. Botterell EH, Wilson KE. Active management (non-operative) of cranio-cerebral injuries (disposition of 180 Canadians and follow-up of 132 patients returned to active service in Canadian Army [overseas]). Can Med Assoc J 1944: 51: 498-509.

43. Botterell EH, Keith WS, Stewart OW. Results of surgical treatment of sciatica due to herniation of intervertebral disc in Canadian soldiers overseas. Can Med Assoc J 1944; 51: 210-214.

44. Botterell EH, Magner D. Meningitis due to Ps.pyocyanea: penetrating wounds to head. Lancet 1945; 1: 112-115.

45. Botterell EH, Jousse AT, Aberhart C, Cluff JW. Paraplegia following war. Can Med Assoc J 1946; 27: 595-623.

46. MacDonald IB, McKenzie KG, Botterell EH. Anterior rhizotomy: accurate identification of motor roots at lower end of spinal cord J Neurosurg 1946; 3: 421-425.

47. Stewart OW, Botterell EH. Cranio-facial orbital wounds involving paranasal sinuses: primary definitive surgical treatment. $\mathrm{Br}$ Surg 1947; 1: 112-118.

48. Denny-Brown D, Botterell EH. Motor functions of agranular frontal cortex. Res Nerv Ment Dis Proc 1947-48; 27: 235-345.

49. Alexander Jr. E, Botterell EH. Unilateral hydrocephalus resulting from occlusion of foramen of Monro: complication of radical removal of brain abscess. J Neurosurg 1949; 6: 197-206.

50. Botterell EH, Callaghan JC, Jousse AT. Pain in paraplegia: clinical management and surgical treatment. Proc Roy Soc Med 1954 47: $281-288$

51. Botterell EH, Horsey WJ. Neurosurgical experiences with diabetes insipidus. Neurology 1955; $5: 449-460$.

52. Cameron GS, Scott JW, Jousse AT, Botterell EH. Diaphramatic respiration in a quadriplegic patient and effect of position on his vital capacity. Ann Surg 1955; 141: 451-456.

53. Botterell EH. Fracture-dislocations of thoraco-lumbar spine with spinal cord injury. Postgrad Med 1956; 20: 177-179.

54. Cannell DE, Botterell EH. Subarachnoid hemorrhage and pregnancy. Am J Obstet Gynecol 1956; 72: 844-855. 
55. Gunton RW, Scott JW, Lougheed WM, Botterell EH. Changes in cardiac rhythm and in form of electrocardiogram resulting from induced hypothermia in man. Am Heart J 1956; 52: 419-429.

56. Zollinger RW, Curry GJ, Botterell EH. Symposium: trauma. Postgrad Med 1956; 20: 423-435.

57. Botterell EH, Fitzgerald GW. Spinal cord compression produced by extradural malignant tumors: early recognition, treatment and results. Can Med Assoc J 1959; 80: 791-796.

58. Botterell EH. Strokes as a neurosurgeon sees them. Postgrad Med 1959; 26: 413-417.

59. Fleming JFR, Botterell EH. Cranial dermoid and epidermoid tumors. Surg Gynecol Obstet 1959; 109: 403-411.

60. Horsey WJ. Botterell EH: Coma: a neurosurgical emergency. Surg Clin North Am 1960; 40: 1311-1330.

61. Botterell EH, Lougheed WM, Morley TP, Tasker RR. Use of radioactive arsenic (As74) in the diagnosis of supratentorial brain tumors. Can Med Assoc J 1961; 85: 1321-1328.

62. Botterell EH. Head injuries. Postgrad Med 1963; 33: 207-209.

63. Botterell EH, Lloyd LA, Hoffman HJ. Oculomotor palsy due to supraclinoid internal carotid artery berry aneurysm. A long-term study of the results of surgical treatments on the recovery of the third-nerve function. Am J Ophthal 1962; 54: 609-616.
64. Botterell EH. Early recognition of brain tumors. Postgrad Med 1964; 36: 297-300.

65. Wortzman G, Botterell EH. A mobile ependymoma of the filum terminale. J Neurosurg 1963; 20: 164-166.

66. Barnett HJ, Botterell EH, Jousse AT, Wynn-Jones M. Progressive myelopathy as a sequel to traumatic paraplegia. Brain 1966; 89: 159-174.

67. Lougheed WM, Botterell EH, Morley TP. Results of the direct attack in the surgical management of internal carotid and middle cerebral aneurysms. Clin Neurosurg 1963; 9: 193-200.

68. Botterell EH, Jousse AT, Kraus SA, et al. A model for the future care of acute spinal cord injuries. Can J Neurol Sci 1975; 2: $361-380$.

69. Botterell EH. Acute cord injury. Part I: milestones in the evolution of management. J R Coll Surg Edinb 1978; 23: 57-64.

70. Botterell. Acute cord injury. Part Il: A study of 224 cases. J R Coll Surg Edinb 1978; 23: 107-116.

71. Hoffman HJ. Reflections on pediatric neurosurgery in America. Concepts in Pediatric Neurosurgery 1983; 3: 12-19.

72. Hoffman HJ. E. Bruce Hendrick. Surg Neurol 1990; 33: 171-172. 